\title{
Holdge
}

If you do not need this report after it has served your purpose, please return it to the Geological Survey, using the official mailing label at the end

UNITED STATES DEPARTMENT OF THE INTERIOR

Harold L. Ickes, Secretary

GEOLOGICAL SURVEY

W. C. Mendenhall, Director

Professional Paper 186-L

\section{THE CORRELATION OF THE UPPER CAMBRIAN SECTIONS \\ OF MISSOURI AND TEXAS WITH THE SECTION \\ IN THE UPPER MISSISSIPPI VALLEY}

BY

JOSIAH BRIDGE

Shorter contributions to general geology, 1936

(Pages 233-237)

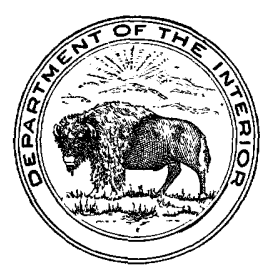

UNITED STATES

GOVERNMENT PRINTING OFFICE

WASHINGTON : 1937

For sale by the Superintendent of Documents, Washington, D. C. 
$\ldots+, \ldots+\infty$ 


\title{
THE CORRELATION OF THE UPPER CAMBRIAN SECTIONS OF MISSOURI AND TEXAS WITH THE SECTION IN THE UPPER MISSISSIPPI VALIAEY ${ }^{3}$
}

\author{
By Josiah Bridge
}

The Upper Cambrian section in the upper Mississippi Valley has long been accepted as the standard for North America, largely because it was the first to bestudied in detail, because it contains a large number of distinct faunas, and because it is still the best-known and the most complete Upper Cambrian section in the Middle West. Various classifications have been proposed from time to time, but the latest and most detailed is that used by the ninth annual field conference of the Kansas Geological Society in the summer of $1935 .^{2}$

It is not the purpose of this paper to discuss the merits and demerits of the Kansas Geological Society's classification, which is frankly a compromise that will require further elaboration, refinement, modification, and the elimination of certain names and their replacement by others before it can be generally accepted. Reference to it in this paper does not imply that it has been accepted either by the writer or by the United States Geological Survey. The proposed reduction of formations to three or four is certainly a step forward, for the Conference seems to have kept the definition of a formation - that is, a cartographic unit-firmly in mind and has drawn the boundaries on that basis. Whether some of the units now classed as members should be regarded as formations or not is beyond the scope of this paper. The proposed column is noteworthy in that it presents the most complete sequence of faunas published to date, and in their proper order, thereby facilitating the correlation with other sections.

Table 1 of this paper presents a tentative correlation of the Upper Cambrian of three different areas-the upper Mississippi Valley, Missouri, and central Texas. The sequence of faunas as worked out in the upper Mississippi Valley is shown in the first column, and the presence of these faunas in the various stratigraphic units is indicated by a dot, or, if doubtful, by an interrogation point.

The determination of the succession of faunas is largely the work of Ulrich and Resser, Edwards, and Raasch; and although they are not in complete agreement concerning details of the stratigraphy, they and all other students of the Upper Cambrian of the Pacific province of North America agree very closely as to the details of the faunal succession.

\footnotetext{
1 Presented before the Paleontological Society, Dec. 27, 1935.

2 Kansas Geol. Soc., Guidebook, Ninth Annual Field Conference, upper Mississippi Valley, p. 18, fig. 1 and elsewhere, 1935.

The upper Mississippi Valley section is dominantly clastic, whereas the sections in Missouri and Texas are in the main calcareous. Therefore, lithologic correlations have been of very little value. Many of the faunas and especially certain elements of them are distinctly facies faunas, and this, together with the lack of study of the Missouri and Texas sections and certain miscorrelations in the upper Mississippi Valley section which have ouly recently been corrected, has greatly retarded correlations among these three areas.

Recent work in Texas by Miss Christina Lochman and the writer has shown that the section in the Central Mineral Region is nearly as complete as the upper Mississippi Valley section and that most of the faunal zones of the latter are present there. As now classified by the United States Geological Survey for the forthcoming geologic map of Texas, the Upper Cambrian of Texas comprises three formations and part of a fourth. These formations were all established on the basis of lithology and without direct reference to the newly proposed upper Mississippi Valley classification. There is, however, a striking similarity between the two classifications.

The Hickory sandstone, which forms the base of the Texas Cambrian section, appears to grade upward into the limestones of the Cap Mountain formation, and together these formations make a unit which is roughly the equivalent of the Dresbach formation of the Conference classification.

As the Hickory thickens the Cap Mountain thins, the combined thickness of the two formations remaining about constant. A further proof of the gradational character of the two formations is the presence of the Cedaria zone in both formations. This relationship will be more fully described in a forthcoming paper by Miss Lochman. The Crepicephalus zone is present, although Crepicephalus itself is not a common form. The dominant genera of this zone are Tricrepicephalus, which extends downward into the Cedaria zone, and Coosia. The Aphelaspis zone, characterized by Aphelaspis depressa (Shumard), is well developed and is probably the most widespread of all the Cap Mountain faunal zones. It occurs in the highest limestone beds of the formation immediately beneath a thick bed of glauconitic sandstone which Paige ${ }^{3}$ included in the Cap

3 Paige, Sidney, U. S. Geol. Survey Geol. Atlas, Llano-Burnet folio (no. 183) p. 45 (field ed.), p. 6 (library ed.), 1912. 
TABLE 1.-Tentative correlation of Upper Cambrian of upper Mississippi Valley, Missouri, and central Texas

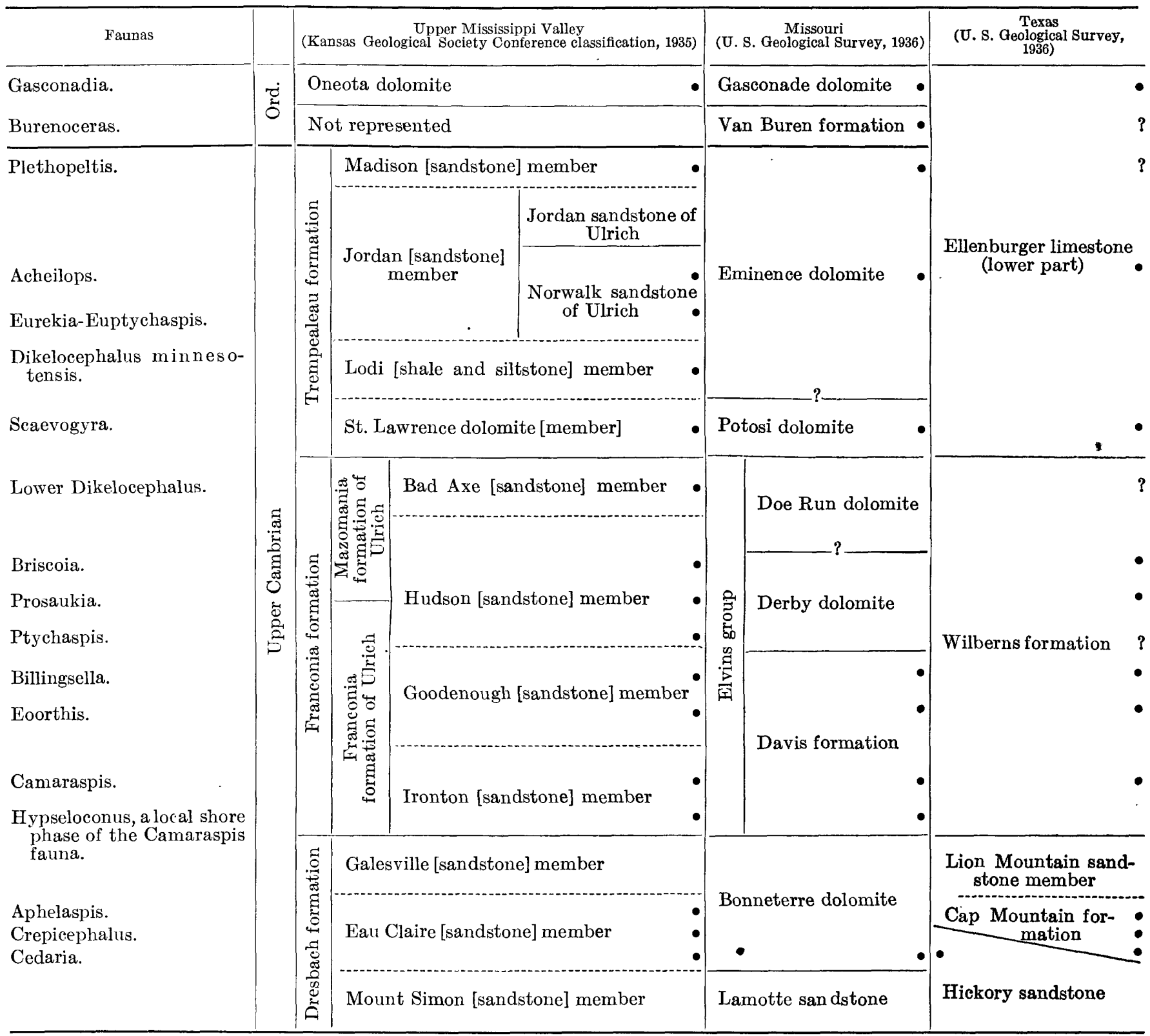

Mountain formation. This sandstone, which is perhaps the best horizon marker in the Central Mineral Region, is here designated the "Lion Mountain sandstone member of the Cap Mountain formation." The name is taken from Lion Mountain, in the northwestern part of the Burnet quadrangle. The section of the Cap Mountain formation exposed along State Highway 29 on the southwest side of Lion Mountain is much thicker and far superior to the type section on Cap Mountain.

The presence of the three faunas in both the upper Mississippi Valley and Texas definitely establishes the squivalence of this part of the section. Whether the Lion Mountain sandstone member is to be considered the full equivalent of the Galesville member of the Conference classification is, of course, purely conjectural.
In Missouri the lower portion of the Upper Cambrian section is composed of the Lamotte sandstone and the Bonneterre dolomite. The contact between the two formations is believed to be gradational, although St. Clair ${ }^{4}$ has postulated an unconformity between them. The Cedaria fauna has been found in the lower 50 feet of the Bonneterre dolomite along the Farmington anticline east of the St. Francois Mountains, where the basal beds are predominantly limestone, and this occurrence serves to tie this portion of the section with the uppermost Hickory and basal Cap Mountain of Texas and with the lower part of the Eau Claire member of the Conference classification for the upper Mississippi Valley. The Crepicephalus and Aphelaspis faunas

4 St. Clair, Stuart, Geology of Ste. Genevieve County, Mo.: Missouri Bur. Geology and Mines, vol. 22, pp. 37, 44, 1928. 
have not been found in Missouri, but one or both of them might well occur in the upper portion of the Bonneterre dolomite, which thus far has̀ yielded no fossils.

Overlying the Cap Mountain formation in Texas is the Wilberns formation, which comprises all the strata between the top of the Lion Mountain sandstone member and the base of the Ellenburger limestone. It is almost exactly the equivalent of the Franconia of the Conference classification, or of the Franconia and Mazomanie of Ulrich's classification. ${ }^{5}$ The base of the Wilberns is marked by the widespread Camaraspis fauna, which serves to correlate it with the Ironton sandstone member of the Franconia. The other important trilobite genera in this asemblage are Elvinia, Burnetia, Housia, Irvingella, and Pterocephalia. Overlying the Camaraspis zone are the Eoorthis and Billingsella or Taenicephalus faunules, which together make up the Conaspis zone and serve to correlate this portion of the Wilberns with the Goodenough member of the Conference classification. The upper zones of the Wilberns are not as definitely known, but the Ptychaspis, Prosaukia, and Briscoia faunas are known to be present, and there are indications of the lower Dikelocephalus zone. These are contained in the socalled "post-Wilberns beds-Fort Sill and Signal Mountain faunal equivalents" of Dake and Bridge, ${ }^{6}$ but until these formations are better known it seems wise to restrict the names "Fort Sill" and "Signal Mountain" to rocks in the type areas (Wichita and Arbuckle Mountains, Okla.). Beds carrying these faunas were locally included in the Wilberns formation by Paige, although at places he assigned beds at the same horizons to the Ellenburger limestone. The Wilberns as now defined includes these beds.

In Missouri the Camaraspis, Eoorthis, and Taenicephalus faunas occur in the Davis formation and serve to correlate it with the lower portion of the Wilberns and with the lower part of the Franconia (Ironton and Goodenough members of the Conference classification). A further tie between Missouri and the upper Mississippi Valley is found in the peculiar assemblage of gastropods known as the Hypseloconus fauna. This is distinctly a facies fauna characteristic of shallowwater conditions along a rocky coast and at present is known from only three localities-one at the base of the Franconia at Taylors Falls, Minn., the other two at the base of the Davis in Missouri.

\footnotetext{
- Ulrich, E. O., Notes on new names in table of formations and on physical evidence of breaks between Paleozoic systems in Wisconsin: Wisconsin Acad. Arts, Sci., and Letters Trans., vol. 21, pp. 72-94, 1924.

'Dake, C. L., and Bridge, Josiah, Faunal correlation of the Ellenburger limestone of Texas: Geol, Soc̣. Amẹriça Bull., vol. 43, pp. 725-741, 1932,
}

The presence of the Camaraspis fauna in the base of the Davis is another reason for assuming that the nonfossiliferous portion of the Bonneterre may represent the Crepicephalus and Aphelaspis zones.

Overlying the Davis are two thin dolomitic formations-the Derby and Doe Run dolomites - which have yielded practically no fossils. Their position in the upper Mississippi Valley and Texas sections is therefore doubtful, but they are believed to represent the upper half of the Wilberns formation and the upper balf of the Franconia, either wholly or in part. There is one tie with the Texas section which of itself is of no great value but which when taken with the general sequence of faunas is at least significant. Near the base of the upper half of the Wilberns formation, in what was called the "Fort Sill faunal equivalent," there are several layers of limestone filled with small spherical bodies which show traces of structure and have been provisionally identified as Girvanella sp. ${ }^{7}$ These bodies occur above the Billingsella zone and beneath the Prosaukia zone. In Missouri small spherical bodies of approximately the same size are found at a definite horizon in the Derby dolomite, but dolomitization has destroyed all traces of structure. These bodies occur above the Taenicephalus zone, but as previously stated the Prosaukia zone has not been recognized in Missouri.

A further reason for correlating the Derby and Doe Run formations with the upper part of the Franconia (Hudson and Bad Axe members of the Conference classification) and with the upper half of the Wilberns is found in the presence of the Scaevogyra fauna in the overlying formation in all three areas. This fauna is characterized by various species of the gastropod Scaevogyra and the trilobites Plethometopus and Platycolpus. It occurs in the St. Lawrence dolomite member of the Trempealeau formation of the Conference classification, in the Potosi dolomite of Missouri, and in the basal portion of the Ellenburger limestone in sections along the Colorado River, Tex., thus serving to correlate the beds in these three areas. This same fauna has been found about 500 feet beneath the top of the Copper Ridge dolomite in eastern Tennessee.

The Trempealeau of the Conference classification is the youngest of the three formations recognized in that classification. It contains several lithologic units, many of which have been accorded formational rank by others. Most of these units contain distinctive faunas. The various classifications in current use are indicated in table 2.

\footnotetext{
' See The geology of Texas, vol. 1: Texas Univ. Bur. Econ. Geology Bull. 3232,
} 1932 . 
TABLE 2.-Various classifications of the late Upper Cambrian strata in the upper Mississippi Valley

\begin{tabular}{|c|c|c|c|c|c|c|}
\hline \multicolumn{2}{|c|}{$\begin{array}{l}\text { Kansas Geol. Soc. Conference, } 1935 \\
\text { (K. G. S. Guidebook, fig. 2) }\end{array}$} & \multirow{2}{*}{\multicolumn{2}{|c|}{$\begin{array}{l}\text { Ulrich, } 1935 \text { (personal communication) } \\
\text { Madison sandstone }\end{array}$}} & \multirow{2}{*}{\multicolumn{2}{|c|}{$\begin{array}{l}\text { U.s. Geol. Surved (present classification) } \\
\text { Madison sandstone }\end{array}$}} & $\begin{array}{l}\text { Minnesota, 1935 } \\
\text { (K. G. S. Guidebook, fig: 2) }\end{array}$ \\
\hline \multirow{6}{*}{ 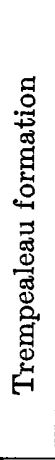 } & $\begin{array}{l}\text { Madison sandstone } \\
\text { member }\end{array}$ & & & & & \multirow{3}{*}{ Jordan sandstone } \\
\hline & \multirow{2}{*}{$\begin{array}{l}\text { Jordan sandstone } \\
\text { member }\end{array}$} & \multicolumn{2}{|c|}{ Jordan sandstone } & \multirow{2}{*}{ 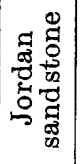 } & Sandstone & \\
\hline & & \multirow{4}{*}{ 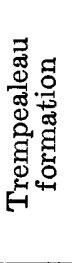 } & Norwalk sandstone & & Norwalk sandstone member & \\
\hline & Lodi shale member & & Lodi shale & 总 & Lodi shale member & \multirow{4}{*}{$\begin{array}{l}\text { St. Lawrence formation } \\
\text { (includes at base shales } \\
\text { and sandstones placed in } \\
\text { underlying formations in } \\
\text { other classifications). }\end{array}$} \\
\hline & St. Lawrence dolomite & & St. Lawrence dolomite & 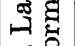 & Mendota dolomite member & \\
\hline & member & & & \multirow{2}{*}{\multicolumn{2}{|c|}{ DIflowe }} & \\
\hline \multicolumn{2}{|c|}{$\begin{array}{l}\text { Franconia formation } \\
\text { Bad axe sandstone member }\end{array}$} & \multicolumn{2}{|c|}{ Mazomanie formation } & & & \\
\hline
\end{tabular}

Overlying the St. Lawrence dolomite member of the Conference classification is the Lodi shale member, which carries the Dikelocephalus fauna, "universally (but with little justification) held to be the type fossil for the Upper Cambrian of the Pacific province." 8 Beds carrying this fauna are not known in Missouri and Texas. Some ascribe this absence to nondeposition of a Lodi equivalent, or to deposition and subsequent erosion, although neither region shows conclusive evidence of a hiatus between the beds carrying the pre- and post-Dikelocephalus faunas. An alternative interpretation is that the Dikelocephalus fauna is made up of forms that lived in the mud and are restricted to areas in which the deposits are shales. This explanation receives additional support from the upper Mississippi Valley, where at some places, according to Raasch, ${ }^{9}$ the shales and siltstones of the Lodi sbale member grade laterally into coarser clastic deposits, which have been called "Norwalk" by Ulrich, and "Jordan" by the Conference; and where this occurs the cbaracteristic Dikelocephalus fauna is replaced by other forms. There are no shales in this part of the section in eitber Missouri or Texas, and this would explain the absence or scarcity of this fauna.

The Norwalk or lower Jordan faunas are still imperfectly known, and more detailed studies must be made before exact correlations are possible. However, Raasch ${ }^{9}$ claims that all the genera described from the Eminence dolomite of Missouri ${ }^{10}$ occur in the Jordan and Madison of Wisconsin. Characteristic genera among the trilobites are Euptychaspis, Triarthropsis, Calvinella, Stenochilina, and Stenopilus. The gastropod Sinuopea is sparingly represented in the Eminence and is abundant at one horizon in the Jordan; these two occurrences mark the first appearance of that genus in these two regions. Near the top of the

\footnotetext{
- Raasch, G. O., Paleozoic strata of the Baraboo area: Kansas Geol. Soc. Guide book, Ninth Annual Field Conference, p. 407, 1935.

- Raasch, G. O., personal communication.

${ }^{10}$ See Missouri Geol. Survey, vol. 24, ch. 6, 1930.
}

Eminence is a zone characterized by several large species of Plethopeltis and Calvinella, which may correspond to the Madison. Raasch records the unique trilobite Entomaspis from the Madison, and the same genus occurs in both the Eminence and Proctor dolomites of Missouri. The Proctor is a unit which some consider to be a distinct formation but which the writer considers to be the upper part of the Eminence formation in certain areas.

The correlation of the Eminence with a zone in the Ellenburger limestone lying above the Scaevogyra zone has been established by the presence of several Eminence species in the Ellenburger, among them Euptychaspis typicalis Ulrich and various species of Stenopilus and Plethopeltis. ${ }^{11}$

In Wisconsin the Madison sandstone is overlain by the Oneota dolomite, of Lower Ordovician age. This formation carries a large molluscan fauna which can be divided into several faunules. It is a widespread fauna and has been recognized in practically every important area of early Ordovician rocks in North America. By means of this fauna the equivalence of the Oneota dolomite with the Gasconade dolomite of Missouri and with beds at a horizon near the middle of the Ellenburger of Texas (the so-called Gasconade faunal equivalent) has been definitely established. All stratigraphers familiar with this portion of the section agree with this correlation.

Among the characteristic gastropods that occur in the three areas under consideration are Gasconadia putilla (Sardeson), Helicotoma uniangulata (Hall), Pelagiella paucivolvata (Calvin), and many species of Ophileta. The cephalopods are represented by several genera, among them Clarkeoceras and Cameroceras, and many species are common to all three areas.

Beneath the Gasconade in Missouri is another formation of Lower Ordovician age, the Van Buren, which

11 Dake, C. L., and Bridge, Josiah, Faunal correlation of the Ellenburger limestone of Texas: Geol. Soc. America Bull., vol. 43, pp. 730-732, 1932. 
carries a fauna related to but different from that of the overlying formation. It is composed primarily of gastropods and cephalopods. Among the gastropods are numerous species of Sinuopea and Schizopea. ${ }^{12}$ Among the cephalopods which appear in this formation in great abundance, various species of Burenoceras and Dakeoceras are especially characteristic. For this reason it is termed the "Burenoceras zone." Strata carrying this fauna are unknown in the upper Mississippi Valley and at present are only doubtfully known from Texas, though there now seems to be reason for believing that this fauna occurs in the Ellenburger limestone in strata lying between beds carrying the Eminence and Gasconade faunas. It is known to occur in the Arbuckle limestone beneath beds carrying the Gasconade fauna. The strata carrying this fauna were probably the initial deposits of the advancing early Ordovician submergence, which did not reach the upper Mississippi Valley.

The correlation of these early Ordovician zones is well established, and the chief innovation of the present correlation is the placing of the Eminence and Potosi of Missouri and their Ellenburger equivalents as correlatives of the Trempealeau formation of the Conference classification.

It has been claimed that correlations based on similar associations of genera are of little or no value, and that the only correlations that can be trusted are those founded on a comparison of finely discriminated species. It is also assumed by some that a fauna, once developed, becomes practically universal in the sea in which it lives, and that it should be present in all the strata deposited in this sea during the time this particular fauna was living. However, there are many examples on record in which strata carrying faunas far more strikingly dissimilar than the ones that are considered to be homotaxial in this paper are correlated with one another because of their stratigraphic position between strata carrying cosmopolitan faunas. Also it is well known that the sea bottom today is not uniformly and universally populated, but that it contains areas which

12 Butts, Charles, Geology of Alabama: Alabama Geol. Survey Special Rept. 14, p. 88 , pl. 14, figs. $23,24,1926$. The name Schizopea Ulrich, 1926, takes precedence over Rhachopea Ulrich and Bridge (Missouri Bur. Geology and Mines, vol. 24, pp. 190-193, 1930), and S. washburnei 3utts must be regarded as the genotype. are crowded with living forms and other areas which are practically barren of life. It is just as logical to assume that two faunas which are for the most part specifically and even generically dissimilar can exist a few hundred miles apart in the same epeiric sea under slightly different environmental conditions as it is to invoke crustal warpings and erosion or nondeposition in order to make two very similar faunas occur in one area at one time and recur in another area at a later time. It is difficult to imagine a sea invading the continent from the southwest, as the Upper Cambrian seas are believed to have done, which would leave a series of deposits such as the Trempealeau formation (Conference classification) in the upper Mississippi Valley and at the same time fail to leave any record of its presence in any of the Cambrian areas to the south of it. It is also equally difficult to imagine how a second sea could come in from the same quarter (it must have done so, because it contains so many identical genera) and leave a second set of deposits in all the areas from which the first set were either eroded or never deposited and at the same time fail to leave a well-defined record in the one area where these earlier deposits remain. Yet these are the assumptions that must be made if the Potosi and Eminence formations of Missouri and the beds of pre-Gasconade age in the Ellenburger of Texas are to be considered as being younger than the Jordan sandstone of the upper Mississippi Valley. No one today questions the practical equivalence of the Cedaria, Crepicephalus, Aphelaspis, Camaraspis, Eoorthis, Taenicephalus, Ptychaspis, Prosaukia, lower Dikelocephalus, and Gasconadia faunas in the three areas under consideration. In view of this striking parallelism it seems more logical to the writer to regard the four known occurrences of the Scaevogyra fauna as a single zone instead of making the occurrence in the St. Lawrence of the Conference classification older than the other three. Similarly it seems best for the present to consider the occurrence of similar forms in the Jordan and Madison of the upper Mississippi Valley, in the Eminence of Missouri, and in the lower part of the Ellenburger of Texas as representing a single horizon instead of placing the upper Mississippi Valley forms in an earlier zone and the others in a later one. 